\title{
中国兰科植物保育的现状和展望
}

\section{罗毅波 贾建生 $^{2}$ 王春玲 $^{2}$}

1 (中国科学院植物研究所系统与进化植物学重点实验室, 北京 100093 )

2 (中华人民共和国林业局保护司，北京 100714)

摘要: 兰科植物是植物保育中的 旗舰” 类群 ( flag group)。中国不是兰科植物种类最丰富的地区, 但具有最复杂多 样的地理分布类型以及众多的原始类群, 因此, 开展对中国兰科植物的研究和保育是世界兰科植物研究和保育工 作中的重要组成部分。本文介绍了目前中国兰科植物研究和保育的现状, 分析了与国际同类工作相比存在的差 距,并对今后的发展方向提出了一些看法。

关键词: 兰科植物, 保育 现状和展望

中图分类号:Q16, Q949.71 ${ }^{+} 8.43$ 文献标识码:A 文章编号 : 1005-0094(2003)01-0070-08

\section{A general review of the conservation status of Chinese orchids}

LUO Yi-Bo ${ }^{1}$, JIA Jian-Sheng ${ }^{2}$, WANG Chun-Ling ${ }^{2}$

1 Laboratory of Systematic and Evolutionary Botany, Institute of Botany, Chinese Academy of Sciences , Beijing 100093

2 Department of Wild Fauna and Flora Conservation and Management, State Forestry Administration, Beijing 100714

\begin{abstract}
Orchids are a flagship group in plant conservation. There are about 1,247 species and about 171 genera in China. The Chinese orchid flora is distinguished by having rich diversity in geographical types, especially by having a broad subtropical area lying between the Qinling Mountains and the Tropic of Cancer. This paper generally reviews the present situation of research and conservation of Chinese orchids. The publication of three volumes of flora of China (Orchidaceae), and some local flora of orchids , such as those for Hainan, Yunnan, Sichuan, and Guangxi Provinces, has laid down a profound foundation not only for correctly identifying and naming Chinese orchids but also for properly making conservation policy and strategies. Compared with relatively rich taxonomic knowledge, however, there is a wide gap in our knowledge of orchid ecology and many other aspects of orchid biology related to conservation. Five main priorities for education and scientific research for the long and short-terms are suggested. First, strengthen and improve basic research such as ecology, biology and floristics. Second, identify and categorize Chinese orchid diversity hot-spots at the country level. Third, promote study of ex situ conservation techniques, particularly developing artificial propagation methods for commercially important species, and starting reintroduction of selected endangered species. Fourth, develop public education programs through school lessons, the press, TV and radio. Finally, establish a scientific information pool at national level.
\end{abstract}

Key words : orchids, conservation, general review

\section{1 前言}

兰科 (Orchidaceae) 是被子植物的大科之一,全 世界约有 700 属近 20000 种 (Atwood, 1986;
Dressler, 1993 ) ,广泛分布于除两极和极端干旱沙 漠地区以外的各种陆地生态系统中，特别是热带地 区的兰科植物具有极高的多样性 (Gustavo，1996)。 中国典型热带地区所占面积不大，因而不是兰科植 
物种类最丰富的地区; 但由于中国跨越热带、亚热带 和温带 3 个气候带以及具有复杂的地理环境, 使得 中国不仅具有各个气候带的兰科植物区系和生态类 型, 并且还保留着许多原始类群 (陈心启，1965， 的, 1982)。特别是中国拥有广阔的亚热带 地区和素有世界屋脊之称的青藏高原等独特地理区 域，其相应的兰科植物区系也是世界上独一无二的 (陈心启，吉占和，1998）。兰科植物俗称兰花，在我 国有近 2000 年的栽培历史( 陈心启，1982，1984）， 是园艺花卉中的重要栽培植物。中国的野生兰花中 有许多是世界级的花卉名品, 如兒兰属 (Paphiopedilum)、杓兰属 (Cypripedium)，独蒜兰属( Pleione)、兰 属 (Cymbidium)、万代兰属 (Vanda) 和石斛属 (Dendrobium) 等。兰科植物的一些种类还具有很高的药 用价值，如天麻(Gastrodia elata)、铁皮石斛(Dendrobium offcinale)、金线莲 (Ludisia discolor) 等。

兰科植物多为珍稀濒危植物, 全世界所有野生 兰科植物均被列入《野生动植物濒危物种国际贸易 公约》的保护范围，占该公约应保护植物的 $90 \%$ 以 上, 是植物保护中的 旗舰” 类群 (flag group)。因 此, 开展对中国兰科植物的研究和保育是世界兰科 植物研究和保育工作中的重要组成部分, 而中国兰 科植物的复杂性使得这项工作的难度更大。自 20 世纪以来, 有关兰科植物保育的基础研究和实际操 作技术得到了长足发展，一些新的技术和方法正被 广泛地运用在就地保育 (in situ conservation) 方面， 如生境的恢复 ( habitat recovery) 及植物回归和复壮 (plant re-introduction and restitution);而保护生物学 各个领域研究的深入以及教育普及工作的开展, 也 极大地推动了迁地保育 (ex situ conservation) 工作。 各种保育措施的整合现已成为许多保育策略和项目 的核心部分。相比之下，我国目前对兰科植物的研 究工作仍侧重于分类描述和系统学研究, 有关保育 的许多基础性研究还处于起步阶段, 有些工作甚至 还未开展。笔者最近参加了在澳大利亚 Perth 举行 的 第一届世界兰花保育大会” , 了解到国际兰科植 物研究和保育的最新进展和发展趋势, 特别是围绕 兰科植物保育而全面开展的各个方面的基础研究工 作, 以及迁地保育方面各种新技术的广泛应用, 如种 子库 (seed bank)、兰科共生真菌的研究等等, 深感 国内有关兰科植物保育的研究与国际同类工作相比 存在不小的差距, 特撰此文, 希望能起到拋砖引玉的
作用，引起国内同行及社会各方面对我国兰科植物 研究和保育工作的关注。

\section{2 中国兰科植物研究和保育现状}

兰科植物保育策略的制定和实施有赖于深入的 研究工作以提供科学依据和资料。一般来讲, 保育 工作涉及两个基本问题:首先要确定哪些类群受到 威胁，急需开展保育工作; 其次是如何采取有效的保 育措施来保护和繁育这些类群。确定受威胁类群所 依据的基本资料涉及到分类学、系统学以及生物地 理学等方面的研究; 制定有效的保育措施则要求必 须对兰科植物有一个全面深刻的认识，涉及到生物 学特性、居群生物学、居群生态学、繁殖生物学等各 个学科的综合研究。

\section{1 中国兰科植物研究现状}

2.1.1 分类、系统和生物地理学研究现状 中国兰 科植物的分类和系统学研究始于 20 世纪 30 年代, 奠基者是唐进、汪发缬两位教授。经过三代兰科分 类学家的不解努力, 中国兰科植物志 (共 3 卷) 终于 在 1999 年正式出版 (郎楷永等, 1999 ;陈心启等, 1999 ;吉占和等，1999），共记载中国兰科植物 171 属 1247 种。兰科植物种类比较丰富的一些省份如 海南、云南、四川和广西等地方性兰科植物专志也已 完成, 正在编纂或印刷过程中。此外, 近 200 篇有关 中国兰科植物分类、系统和进化的研究论文也陆续 在国内外发表。这些工作不但为正确鉴定和命名中 国兰科植物奠定了基础，而且为制定兰科植物保护 策略提供了基本的参考数据,同时也为我国履行 《野生动植物濒危物种国际贸易公约》提供了科学 依据。与其他生物类群一样, 兰科植物的地理分布 往往是不均匀的, 存在一些明显的 分化中心” “生 境多样性中心”或 特有中心”等。确定这样的中心 地区，对制定兰科植物就地保护策略具有重要意义， 因而是一个应该优先考虑的问题。我国学者从植物 区系的角度对兰科植物分布的式样进行了许多有意 义的探讨 (郎楷永, $1980,1983 \mathrm{a}, \mathrm{b}, 1985,1986$ ， 1990,1994 ; 吉占和，1993;Chen , 1983,1996 ; 陈心 启，1998），但从就地保护的角度确定兰科植物就地 保护重点或热点 ( hot spots) 地区仍需进一步的调查 和研究。

2.1.2 居群生态学和生物学研究现状 居群生态 学研究不仅可以使我们了解不同物种对生境的特殊 
要求,也是我们分析物种受生态因素威胁状况的重 要资料来源。《中国植物志》对兰科植物每个种的 生境均有简单的记述，一些基本的资料如土壤、坡 向、伴生植物等在少数类群中也有较详细的记录, 如 兒兰属（Tsi et al. , 1999 ;Cribb \& Luo , 1998 , 1999; Cribb et al. , 1998, 1999a ,b c ,d ;Luo ,2001) 和其他 少数种类 ${ }^{(1)}$ 。但由于中国兰科植物极为复杂的生 态环境,需要对更多的代表类群进行详细的生态调 查, 才能对物种所受生态因素的影响进行较为客观 的评估，从而为有效地进行就地保护提供基础和指 导。

居群生物学包括居群统计学 (demography)、居 群遗传学 (population genetics) 和传粉生物学 (pollination biology) 等许多内容。居群统计学研究是制 定保护策略的重要依据之一。兰科植物的一些种类 居群密度相当高, 每公顷面积上可生长数千株个体, 但也有些种类的居群密度非常低,每公顷仅有少数 几株。我国在这方面的研究尚属空白。居群遗传结 构及其影响因素等方面的研究对物种及居群的恢复 和重建至关重要，可以为保护特定的基因型提供准 确指导, 可以确定重建居群的变异程度以及了解居 群之间是否通过交配和基因流而发生联系。这方面 的研究我国仅在兒兰属和独花兰属 (Changnienia) 等少数类群中开展了一些有意义的尝试 ( Li et al. , $2002 \mathrm{a}, \mathrm{b})$ 。传粉生物学的研究对兰科植物的保育 同样具有重要意义，因为大多数兰科植物与传粉昆 虫在进化过程中形成了完美的协同进化关系,有些 甚至形成了一对一的专性传粉关系; 如果传粉者受 到威胁, 就会直接影响到相应兰科植物的结实能力, 从而影响到该种兰科植物的生存。特别是在为受威 胁物种制定恢复 (recovery) 方案时，要制定一些特殊 的措施来保证传粉者对受威胁物种进行长期、有效 的传粉活动, 这就必须要有传粉生物学研究作为基 础。我国目前已开始开展这方面的研究 (Luo \& Chen，1999），但类似的工作还太少，对我们制定保 育策略极为不利。

研究兰科植物的生活史, 可以帮助我们了解维 持该物种生存的生态环境及其生活史的不同阶段所 需的最佳生境，以及为创造或维持最佳生境所必需 采取的管理措施。毫无疑问,生物学特性的研究数 据对于有效管理野生兰科植物居群以及预测它们的 未来命运等方面均有重要意义。迄今为止, 我国仅
有极少数兰花物种有生活史和生物学特性方面的报 道(刘芳媛，张应，1975; 周铉，1981; 翁恩生等， 2002 ）对兰科植物个体在自然条件下的寿命及其 居群的年龄结构等方面仍然知之甚少。

2.1.3 繁殖生物学研究现状 利用组织培养的方 法进行大规模克隆繁殖 (clone propagation), 无疑可 以减轻对野生兰科植物的采集压力,但到目前为止 仅有少数兰科植物在组培上取得了成功。我国在 20 世纪 70 年代末就开始进行兰属植物组织培养方 法的研究, 并取得了阶段性成果( 孙安慈, 个人通 信),但尚未得到广泛应用。目前组织培养方法主 要用于蝴蝶兰 ( standard Phalaenopsis)、大花蕙兰 ( standard Cymbidium) 以及其他杂交观赏兰花的生 产。另一方面, 兰科植物的种子非常细小，一个蒴果 中有几十万到上百万粒种子，因而利用种子进行萌 发也可以达到大规模繁殖的目的。由于兰科植物微 小的种子本身无法䇄存养分，自然条件下，其种子萌 发阶段完全依靠菌根真菌为其提供养分 (陈心启, 吉占和，1998；Koopowitz，2001)。兰科植物成年植 株对共生真菌的依赖程度不同，一般来说 地生类兰 科植物较附生类依赖程度更高。在人工条件下附生 兰和地生兰的一些种类均可以在无菌条件下生长。 尽管如此, 研究兰科植物与共生真菌的关系以及利 用共生真菌来促进种子萌发和幼苗生长已成为兰科 植物繁殖生物学研究的重要方向。有关药用植物天 麻 (Gastroia elata) 与共生真菌关系的研究最为典 型，Kusano (1911) 首先报道了天麻的营养生长与共 生真菌一密环菌 (Armilariella mella) 之间的关系, 为人工无性繁殖栽培天麻奠定了基础;而徐锦堂等 (1981) 以及徐锦堂和郭顺星 (1989) 发现了天麻种 子在萌发阶段所必需的另一种共生真菌一一紫箕小 菇 (Mycena osmundicola) , 则为天麻有性繁殖的成功 提供了可能。毫无疑问, 这两个重大的发现使得我 国天麻人工繁殖取得了完全成功。类似的工作在细 叶石斛 (Dendrobium hancockii)、墨兰 (Cymbidium sinense)、铁皮石斛 (Dendrobium officinale) 和花叶开 唇兰 (Anoectochilus roxburghii) 等种类中也开展过一 些( 郭顺星，徐锦堂,1990a，b ;范黎等,1996 ;郭顺

(1) Luo Y B , 2003. An addition to the Chinese Saprophytic Orchidsnote of Epipogium japonicum from China. Orchid Review , ( in press) (2) Luo Y B , 2003. The true identity of Habenaria purpureopunctata K. Y. Lang , a distinctive orchid from southeast Xizang and northeast India. Orchid Review , ( in press) 
星,范黎，1997 郭顺星等，1999），但未能在这些兰 科植物的人工栽培和繁殖中取得较大的突破。

\section{2 中国兰科植物的保护现状}

由于兰科植物的重要性，不少国家和地区将本 地区所有野生兰科植物置于其法律保护的范围。由 于种种原因，我国尚未将野生兰科植物列入《国家 重点保护野生植物名录》,兰科植物的保护在我国 尚缺乏法律依据。1992 年出版的中国植物红皮书 (第一册)（傅立国，1992）也仅列入 7 种兰科植物。 尽管我国自 20 世纪 50 年代中期开始建立自然保护 区，而且这些保护区在保护兰科植物及其生境等方 面已起到了积极作用，但兰科植物的保护在中国仍 面临着严峻的挑战,最主要的问题是生境的破坏和 丧失以及人为过度采集。迄今为止，我国还没有针 对兰科植物而设立的自然保护区、保护小区或保护 点。众所周知，兰科植物的营养体非常类似，仅靠营 养体是难以准确鉴定的,正是基于这种实际操作上 的困难 《野生动植物濒危物种国际贸易公约》将所 有兰科植物列于其附录中。而我国仅 7 种兰科植物 被列入植物红皮书，给实际保护和管理带来了许多 困难。因此，许多自然保护区的物种编目中兰科植 物种类收集不全,有些甚至没有兰科植物。上述种 种问题的存在使得保护区对兰科植物的就地保护作 用遭到严重削弱。迁地保护方面，尽管全国不少机 构收集引种了一定数量的兰科种类, 但主要是以引 种为目的, 真正意义上的迁地保护工作目前尚未开 展。

\section{3 中国兰科植物持续利用现状}

我国栽培兰花的历史已有 2000 余年 (Chen \& Tang，1982），但整体上兰科植物的利用仍处于直接 从自然界获取的低级阶段。造成这种现象的主要原 因在于以下几个方面: 1 ) 繁殖方法没有突破性进 展。我国目前除天麻和铁皮石斛等极少数种类大规 模人工栽培获得成功外，其他野生兰科植物仍然依 靠传统的分株繁殖, 繁殖效率低, 且要求有很大的母 株库，即需要有很大的繁殖基数才有可能达到规模 繁殖的目的。2)人工杂交育种没有得到发展和普 及, 仍主要依赖从野生植株中进行品种篮选。以国 兰为例，早在 1000 多年前人们就已经开始从野生植 株中䇻选栽培品种, 但到目前为止仍然停留在这种 阶段。为了得到一些稀有品种，一些商家不惜成吨 收购野生植株，从中选取极少量稀有品种后，将大部
分植株作为垃圾扔掉，这对兰花资源无疑是一种毁 灭性的利用。如果利用人工杂交方法进行定向杂交 组合,所得到的变异品种肯定比自然界的天然突变 品种要丰富得多, 并且也容易得到理想的品种。蝴 蝶兰工业化生产的发展历程就是一个极好的例子， 如果没有人工杂交后代，今日如此丰富多彩的蝴蝶 兰品种系列是无法想象的。3)野生兰科植物资源 利用方法单一。我国有如此丰富的兰科植物生态类 型，是开展兰花生态旅游的理想地区，但极少有风景 旅游区或自然公园将野生兰花植物作为旅游资源来 开发和利用。这方面我们急需借鉴国外的成功经 验。4)野生药用兰科植物资源开发无序。作为药 用植物，野生植株如果能得到合理利用，每年能产生 相当可观的经济效益。但目前我国由于在采集方式 和采集量等方面的管理措施失控,野生资源受到毁 灭性的破坏，更谈不上采取人工回归” (re-introduction)、改善生长环境、增加居群数量和产量等科学 管理措施。

\section{3 研究和保育工作与国际同类工作相比存} 在的主要差距

通过这次 Perth 会议可以看出，我国在兰科植 物研究和保育方面与国际先进水平相比存在较明显 的差距。特别表现在以下 3 个方面:1) 保育目标的 确定。一个物种的保育, 必须建立在对这个物种进 行全面研究的基础上。由于受各方面因素的限制, 这种全面的基础研究只有在一些最重要的保护类群 中才能开展。因此, 集中有限的资源对这些最重要 的类群进行全面研究是十分必要的。在一些保育工 作做得较好的国家和地区如澳大利亚，已经有明确 的重点保护种类和保护地区的名录，而我国至今还 没有一份类似的名录。2) 在居群水平上对兰科植 物进行监测 (monitor) 是判断管理措施是否有效的 主要方法，它不仅可以监测兰科植物的自然生长状 况, 还可以定期评估管理措施的实际效果。多年连 续的监测活动还可以帮助人们认识兰科植物居群自 然变化的过程,从而可以确认个体数目的变化是受 人为影响还是受其本身自然变化的影响。因此,对 保护类群在居群水平上进行监测是反映实施人工管 理措施成效的最主要的指标。国际上已有很多成功 的例子 (Stuckey，1967; Tamm，1972 ; Hutchings , 1987 ; Mehrhoff ,1989)。3) 迁地保护。当某种兰科 
植物的生境面临完全丧失的危险或受到过大的商业 采集压力时,迁地保护就成为惟一可行的保育措施。 生境丧失和过度采集在我国十分严重, 但我国目前 在迁地保护方面的组织协调性比较差, 尚未形成迁 地保护网络。以兒兰属 (Paphiopedilum) 为例, 有不 少研究机构和花卉公司均开展过该属的迁地保护工 作, 但是, 由于没有居群遗传学研究资料或相关研究 作基础,使得这些工作的实际保护效果大为降低。 此外, 由于缺乏有效的组织协调, 使得迁地保护工作 本身就已经对我国野生兒兰属植物构成了一定程度 的危害。更遗憾的是，一些机构因缺乏后续资金以 及科学的管理方法,曾经收集到的许多资源也已经 遗失。迁地保护存在的另一方面的问题是方法和技 术落后。应用于兰科植物迁地保护的一种重要方法 是利用共生真菌促进兰科植物种子萌发和幼苗生 长，从而达到大规模繁殖的目的。该项技术是目前 国际上常用的一种行之有效的技术，它不仅可以提 高种子的萌发率, 而且还可以促进幼苗生长以及花 芽的形成和分化，缩短兰科植物的开花周期。采用 共生真菌培育的植株更适合于移栽到自然环境, 有 利于开展 回归”工作。遗憾的是我国对兰科共生 真菌的有关研究重视不够, 仅在天麻等少数类群中 开展过这方面的工作。

\section{4 中国兰科植物研究、保育策略和发展方向 的探讨}

4.1 加强兰科植物生态学、居群生物学、分类以及 地理分布的研究

准确、全面地收集每个种的分布地点、繁殖特 征、传粉媒介、生境需求、相对居群数量和大小以及 居群的遗传结构等基础资料, 既是科学评价物种濒 危等级的重要依据, 也是制定具体保育措施的科学 基础。通过几十年的工作和积累, 我国兰科植物研 究者基本掌握了中国兰科植物的分类和分布状况。 但由于中国幅员辽阔，从事兰科植物研究的人员有 限, 调查覆盖的地区以及调查的深度均受到一定限 制。现有关于兰科植物的资料, 特别是有关地理分 布方面的资料仍很欠缺, 如在贵州东北部发现了硬 叶兒兰 (Paphiopedilum microarnhum) 新的分布点 ( Cribb et al. , 2002) ;许多新类群的发现和新的分 布记录报道(Cribb \& Chen , 1999 ; 陈心启等 ,2001； 钱义咏，2001; 张建勇等，2001; 陈心启,罗毅波，
2002 ; Holger ,2002; 金效华等，2002;郎楷永，萧丽 萍，2002; 刘仲健，陈心启，2000a，2000b，2001， 2002 ; 刘仲健，张建勇，2000，2001，2002; 刘仲健 等,2000,2001,2002a ,b; 罗毅波,陈心启,2002)均 表明兰科植物的分类和地理分布调查仍有大量工作 要做。此外,除自兰属、独花兰属等少数种类外，绝 大多数种的生态学和生物学特征、居群数量和大小 以及居群遗传结构等方面的工作仍是空白, 这必然 影响对兰科植物物种濒危级别的准确认定以及保育 策略的制定。因此，继续加强对兰科植物的基础性 研究仍然是十分必要的。

4.2 在现有的研究基础上确定中国重点兰科植物 保育种类和重点保育地理范围

建立自然保护区是进行物种就地保护的有效方 式, 特别是兰科植物, 由于鉴定和识别难度较大, 而 我国目前又未将整个兰科植物纳入保护法律系统 下,使得建立自然保护区成为保护兰科植物的惟一 途径。因此，尽快在现有资料的基础上，在兰科植物 种类丰富的地区建立保护区、保护小区、保护点和禁 采地, 是实行就地保护的当务之急。在迁地保育方 面, 由于受到人力、物力资源的限制，必须根据实际 情况制定出一个最需要采取保护措施的兰科植物种 类名单，根据这个名单开展各个方面的工作。

4.3 加大规模繁殖方法的研究, 积极开展 回归” 工作

规模繁殖不仅可以为迁地保护提供技术上的可 行性，而且是开展 回归”工作和恢复野生居群的基 础。规模繁殖成功还可以极大减缓对野生资源的需 求压力。因此开展规模繁殖的研究是目前中国兰科 植物保育工作中最为迫切也最为重要的课题。此 外, 在开展 回归”工作时, 要注意与居群遗传学研 究相结合, 以便于评估 回归”植物对原产地生境的 适应过程以及对野生植株生态和遗传学方面的影 响。

4.4 加大对兰科植物保护重要性的宣传力度, 促进 兰花生态旅游的发展

近年来，人们对保护环境和野生动植物的关注 程度越来越高, 但由于种种原因, 人们对兰科植物这 种小型植物的保护意识远不及对树木的强, 相当多 的人认为兰科植物不是受保护的类群。此外人们一 般仅关心兰科植物的观赏价值和药用价值,而基本 上没有意识到其潜在的旅游价值。实际上早在 20 
世纪 80 年代初兰花生态旅游就开始在国际流行。 我国兰科植物种类和生态类型比较丰富,尤其是亚 热带和高山兰科植物更是我国独有的资源, 开展兰 花生态旅游有着得天独厚的条件。

\section{5 建立中国兰科植物研究和保育的信息交流网} 络

由于兰科植物的栽培和繁殖技术难度较大, 仅 仅依靠传统的方法难以取得良好的效果。中国有许 多兰花爱好者,他们常收集国兰等多种兰花品种，因 此, 若能将各地有关的科研机构、栽培爱好者等组织 起来，建立中国兰科植物研究和保育信息交流协作 网络，介绍先进的栽培和繁殖方法,交流各地有关兰 科植物的栽培信息和资料，一定能促进我国兰科植 物研究和保育工作的开展。

\section{参考文献}

Atwood J T Jr, 1986. The size of the Orchidaceae and the systematic distribution of epiphytic orchids. Selbyana, 9: 171 $\sim 186$

Chen S C (陈心启), 1965. A primitive new orchid genus Tangtsinia and its meaning in phylogeny. Acta Phytotaxonomica Sinica (植物分类学报), 10(3)：193 206 (in Chinese)

Chen S C (陈心启), 1978. Sinorchis - a primitive new genus of Orchidaceae from China. Acta Phytotaxonomica Sinica (植 物分类学报), 16(4):82 85 (in Chinese)

Chen S C (陈心启), 1979. On Diplandrochis, a very primitive and phylogentically significant new genus of Orchidaceae. Acta Phytotaxonomica Sinica (植物分类学报), 17(1)：1 $\sim 6$ (in Chinese)

Chen S C (陈心启), 1982. The origin and early differentiation of the Orchidaceae. Acta Phytotaxonomica Sinica (植物分 类学报), $20(1): 1 \sim 22$ (in Chinese)

Chen S C and T Tang, 1982. A general review of the orchid flora of China. In: J Arditti (ed.), Orchid Biology, Review and Perspectives. Cornell University Press, New York, 2: $39 \sim 81$

Chen S C, 1983. A comparison of orchid floras of temperate North America and eastern Asia. Annals of the Missouri Botanical Garden, 70(4): 713 723

Chen S C, 1984. A survey of orchid cultivation and appreciation in ancient China. Proceedings of 1 st Asia Pacific Orchid Conference, $18 \sim 22$

Chen S C, 1996. Orchids, north Asia and Japan. In: IUCN, SSC (eds.), Orchid Specialist Group: Orchids, Status Survey and Conservation Action Plan, IUCN Publication Services Unit Press, $85 \sim 88$

Chen S C (陈心启), 1998. A comparison of orchid floras of Taiwan and the mainland of Asia. In: S T Chiu (邱少婷) and C I Peng (彭镜毅) ( eds.), Proceedings of the Crossstrait Symposium on Floristic Diversity and Conservation (海 峡两岸植物多样性与保育论文集). National Museum of Natural Science, Taichung, $107 \sim 114$ (in Chinese)

Chen S C (陈心启) and Z H Tsi (吉占和), 1998. The Orchids of China. Forestry Press, Beijing (in Chinese)

Chen S C (陈心启) and Y B Luo (罗毅波), 2002. An additional note on Chinese Otochilus (Orchidaceae). Acta Phytotaxonomica Sinica (植物分类学报)，40(2)：151 153 (in Chinese)

Chen S C (陈心启), Z H Tsi (吉占和), K Y Lang (郎楷永) and G H Zhu (朱光华), 1999. Flora Reipublicae Popularis Sinicae Tomus 18. Science Press, Beijing ( in Chinese)

Chen S C (陈心启), Z J Liu (刘仲健) and J Y Zhang (张建 勇), 2001. A new species and a new variety of Paphiopedilum (Orchidaceae). Acta Phytotaxonomica Sinica (植物 分类学报), 39(5)：455 458 (in Chinese)

Chow S (周铉), 1981. The life circle of Gastrodia elata Blume. Acta Botanica Yunnanica (云南植物研究), 3 (2)：197 202 (in Chinese)

Cribb P, S C Chen, 1999. A new species of Cypripedium from South-east Yunnan. Quarterly Bulletin of the Alpine Garden Society, 67(2): $155 \sim 158$.

Cribb P and Y B Luo, 1998. Paphiopedilum malipoense in China. Orchid Review, 1224: $343 \sim 345$

Cribb P, Y B Luo and G Siu, 1998. Paphiopedilum armeniacum in its natural habitat in western Yunnan. Orchid Review, 1223: $271 \sim 273$

Cribb P and Y B Luo, 1999. Paphiopedilum malipoense in China. Orchid Conservation News, 1: 9 10

Cribb P, Y B Luo, N McGough and G Siu, 1999a. The distribution, ecology and conservation status of Paphiopedilum micranthum (Orchidaceae) in South-west China. Orchid Review, 1227: $149 \sim 152$

Cribb P, Y B Luo and G Siu, 1999b. Paphiopedilum hirsutissimum var. esquirolei in southern China. Orchid Review, 1228: $217 \sim 219$

Cribb P, Y B Luo and G Siu, 1999c. Paphiopedilum dianthum in south-east China. Orchid Review, 1229: $289 \sim 291$

Cribb P, Y B Luo and S Gloria, 1999d. Paphiopedilum concolor (Lindl. ) Pritzer und bellatulum (Rchb. F.) Stein in China. Die Orchidee, 50(4): $378 \sim 382$

Cribb P, Y B Luo and G Siu, 2001. Observations on Paphiopedilum emersonii in southeast Guizhou. Orchid Review, 1242: $351 \sim 355$

Cribb P, Y B Luo and G Siu, 2002. Paphiopedilum micranthum in North-east Guizhou, a significant range extension. Orchid Review, 1243: $40 \sim 43$

Dressler R L, 1993. Phylogeny and Classification of the Orchid Family. Cambridge University Press, Cambridge

Fan Li (范黎), S C Guo (郭顺星), J T Xu (徐锦堂) and W Q Cao (曹文芩), 1996. Isolation, culture, identification and biological activity of Mycena orchidicola sp. nov. in Cymbidium sinense (Orchidaceae). Acta Mycologica Sinica 
(真菌学报), 15(4): 251 255 (in Chinese)

Fu L K (傅立国), 1992. China Plant Red Data Book: Rare and Endangered Plants (I). Science Press, Beijing

Guo S X (郭顺星) and J T Xu (徐锦堂), 1990a. Determination of primary metabolic products of fungi promoting seed germination of Gastrodia elata Bl. and other Orchidaceae medicinal plants. China Journal of Chinese Material Medica (中国中药杂志), 15(6)：12 14 (in Chinese)

Guo S X (郭顺星) and J T Xu (徐锦堂), 1990b. Effects of fungi and its liquid extract on seed germination of Dendrobium hancockii Rolfe. China Journal of Chinese Material Medica (中国中药杂志), 15(7): 13 15 (in Chinese)

Guo S X and L Fan, 1997. Mycena anoectochila sp. nov. isolated from myccorrhizal roots of Anoectochilus roxburghii from Xishuangbanna, China. Mycologia, 89(6) : $952 \sim 954$

Guo S X (郭顺星), L Fan (范黎), W Q Cao (曹文芩), X M Chen (陈晓梅), 1999. Mycena dendrobii, a new mycorrhizal fungus. Mycosystema (菌物系统), 18(2): 141 144. (in Chinese)

Gustavo A R, 1996. The orchid family. In: IUCN/SSC Orchid Specialist Group (ed.), Orchids-Status Survey and Conservation Action Plan. IUCN, Gland, Switzerland and Cambridge, UK. $3 \sim 4$

Holger P, 2002. Cypripedium sichuanense-eine neue Frauenschunhorchidee der Sektion Trigonopedia Franchet aus China. Die Orchidee, 53(1): $89 \sim 94$

Hutchings M A, 1987. The population biology of the early spider orchid, Ophrys sphegodes Mill. I. A demographic study from 1975 to 1984. Journal of Ecology, 75: $711 \sim 727$

Jin X H (金效华), Z H Tsi (吉占和), H N Qin (覃海宁), G Siu (萧丽萍) and P Jian (塞平), 2002. Novelities of the Orchidaceae of Guizhou, China. Acta Phytotaxonomica Sinica (植物分类学报), 40 (1): $82 \sim 88$ (in Chinese)

Koopowitz H, 2001. Orchids and Their Conservation. B T Batsford Ltd., London

Kusano S, 1911. Gastrodia elata and its symbiotic association with Armillaria mella. Journal of College Agricultural Imperial University Tokyo, 4: $1 \sim 66$

Lang K Y (郎楷永), 1980. A study on the geographical distribution and floristic features of the Xizang (Tibet) orchid flora. Acta Phytotaxonomica Sinica (植物分类学报), 18 (4) : $391 \sim 407$ (in Chinese)

Lang K Y (郎楷永), 1983a. The geographical distribution and floristic features of the orchid flora in the Mt. Emei in China. Acta Phytotaxonomica Sinica (植物分类学报), 21 (3) : $254 \sim 265$ (in Chinese)

Lang K Y (郎楷永), 1983b. The geographical distribution and floristic composition of the orchid flora in Yulong Shan, Lijiang, in north-western Yunnan. In: H L Sun (孙鸿烈) et al., (eds.), Studies in Qinghai-Xizang (Tibet) Plateau Special Issue of Hengduan Mountains Scientific Expedition (横断山考察集)，1: 264 269 (in Chinese)

Lang K Y (郎楷永), 1985. The geographical distribution and floristic composition of the orchids in the Gongga Moutain region, Sichuan. Acta Phytotaxonomica Sinica (植物分类
学报), 23(6): $418 \sim 428$ (in Chinese)

Lang K Y (郎楷永), 1986. The geographical distribution and floristic features of the orchids in the Wolong Nature Conservation Area. In: H L Sun (孙鸿烈) et al., ( eds.), Studies in Qinghai-Xizang (Tibet) Plateau Special Issue of Hengduan Mountains Scientific Expedition (横断山考察 集), 2: $432 \sim 441$ (in Chinese)

Lang K Y (郎楷永), 1990. Notes on the orchid flora in the Hengduan Mountain region, China. Acta Phytotaxonomica Sinica (植物分类学报), 28(5): 356 371 (in Chinese)

Lang K Y (郎楷永), 1994. Studies on the distribution patterns of some significant genera in orchid flora. Acta Phytotaxonomica Sinica (植物分类学报), 32(4)：328 339 (in Chinese)

Lang K Y (郎楷永) and G Siu (萧丽萍), 2002. A new species of Anoectochilus Blume (Orchidaceae) from China. Acta Phytotaxonomica Sinica (植物分类学报), $\mathbf{4 0}(2)$ : $164 \sim 166$ (in Chinese)

Lang K Y (郎楷永), S C Chen (陈心启), Y B Luo (罗毅波) and G H Zhu (朱光华), 1999. Flora Reipublicae Popularis Sinicae Tomus 17. Science Press, Beijing (in Chinese)

Li A, Y B Luo and S Ge, 2002a. A preliminary study on conservation genetics of an endangered orchid (Paphiopedilum micranthus) from southwestern China. Biochemical Genetics, 40: $195 \sim 201$

Li A, Y B Luo, Z T Xiong and S Ge, 2002b. A preliminary study on conservation genetics of three endangered orchid species. Acta Botanica Sinica, 44 (2): $250 \sim 252$

Liu F Y (刘芳媛) and Y Zhang (张应), 1975. Biological observations on Gastrodia elata Bl. Acta Botanica Yunnani$c a$ (云南植物研究), 1 (1): $45 \sim 49$ (in Chinese)

Liu Z J (刘仲健) and S C Chen (陈心启), 2000a. Paphiopedilum angustatum, a new orchid from Yunnan, China. Acta Phytotaxonomica Sinica (植物分类学报), 38(5)：464 466 (in Chinese)

Liu Z J (刘仲健) and S C Chen (陈心启), 2000b. Cymbidium rigidum sp. nov., a new orchid from Yunnan, China. Acta Phytotaxonomica Sinica (植物分类学报), $\mathbf{3 8}(\mathbf{6}): 570 \sim$ 572 (in Chinese)

Liu Z J (刘仲健) and S C Chen (陈心启), 2001. Paphiopedilum microchilum, a new species of Orchidaceae from Yunnan, China. Acta Phytotaxonomica Sinica (植物分类学 报), 39(2): 156 159 (in Chinese)

Liu Z J (刘仲健) and S C Chen (陈心启), 2002. Paphiopedilum densissimum, a new species of Orchidaceae from Yunnan, China. Acta Phytotaxonomica Sinica (植物分类学 报), 40(3): $283 \sim 285$ (in Chinese)

Liu Z J (刘仲健) and J Y Zhang (张建勇), 2000. Paphiopedilum singchii sp. nov., an addition to the subgenus Brachypetalum of Paphiopedilum (Orchidaceae). Acta Phytotaxonomica Sinica (植物分类学报), 38(5): 467 470 (in Chinese)

Liu Z J (刘仲健) and J Y Zhang (张建勇), 2001. Paphiopedilum armeniacum var. parviflorum, a new orchid variety 
from southwestern China. Acta Phytotaxonomica Sinica (植 物分类学报), 39(5): 459 460 (in Chinese)

Liu Z J (刘仲健) and J Y Zhang (张建勇), 2002. Paphiopedilum multifolium, a new species of Orchidaceae from Yunnan. Acta Botanica Yunnanica (云南植物研究), 24(2): $191 \sim 192$ (in Chinese)

Liu Z J (刘仲健), S C Chen (陈心启), J Y Zhang (张建勇), 2002a. Additional notes on the subgenus Brachypetalum (s. 1.) of Paphiopedilum. Acta Phytotaxonomica Sinica (植物分类学报), 40(3): 364 370 (in Chinese)

Liu Z J (刘仲健), S C Chen (陈心启), J Y Zhang (张建勇) and S P Lei (雷嗣鹏), 2002b. A taxonomical note of Paphiopedilum malipoense and its allies. Acta Botanica Yunnanica (云南植物研究), 24(2)：193 198 (in Chinese)

Liu Z J (刘仲健), J Y Zhang (张建勇) and Q L Luo (罗秋 林), 2001. A new species of Paphiopedilum (Orchidaceae) from Yunnan, China. Acta Phytotaxonomica Sinica (植 物分类学报), 39(6)：156 159 (in Chinese)

Liu Z J (刘仲健), J Y Zhang (张建勇), X M Xu (徐向明) and J H Ma (马京华), 2000. Notes on Paphiopedilum concolor and its allies. Acta Botanica Yunnanica (云南植 物研究), 22(4): 390 394 (in Chinese)

Luo Y B, 2001. The genus Hemipilia-seven terrestrial orchids relatively unknown to hobbyists. The Magazine of the American Orchid Society, 70(7): $642 \sim 649$

Luo Y B and S C Chen, 1999. Observations of putative pollinators of Hemipilia flabellata Bur. et Franch. (Orchidaceae) in north-west Yunnan Province, China. Botanical Journal of the Linnean Society, 131: $45 \sim 64$

Luo Y B (罗毅波) and S C Chen (陈心启), 2002. Critical notes on the genus Epipogium (Orchidaceae). Acta Phytotaxonomica Sinica (植物分类学报), 40(5)：449 452 (in Chinese)

Mehrhoff L A, 1989. The dynamics of declining population of Tolumnia variegata (Orchidaceae). Oecologia, 94: 361 367

Qian Y Y (钱义咏), 2001. A new species of Brachycorythis Lindl. (Orchidaceae) from Yunnan, China. Acta Phytotax- onomica Sinica (植物分类学报)，39(3)：278 279 (in Chinese)

Stuckey I H, 1967. Environmental factors and the growth of native orchids. American Journal of Botany, 54: $232 \sim 241$

Tamm C O, 1972. Survival and flowering of some perennial herbs. II. The behaviour of some orchids on permanent plots. Oikos, 23: $23 \sim 28$

Tsi Z H (吉占和), 1993. Orchid flora in the Fanjingshan Mountains, southwest China. Bulletin of Botanical Research (植物研究), 13(4): $319 \sim 329$ (in Chinese)

Tsi Z H, Y B Luo, P Cribb, N McGough, Siu G and L Chau, 1999. A preliminary report on the population size, ecology and conservation status of some Paphiopedilum species (Orchidaceae) in South-west China. Lindleyana, 14(1): 12 23

Tsi Z H (吉占和), S C Chen (陈心启), Y B Luo (罗毅波) and G H Zhu (朱光华), 1999. Flora Reipublicae Popularis Sinicae Tomus 19. Science Press, Beijing (in Chinese)

Weng E S (翁恩生), H Hu (胡虹), S Y Li (李树云) and J L Huang (黄家林), 2002. Differentiation of flower bud of Cypripedium flavum. Acta Botanica Yunnanica (云南植物 研究), 24(2): 222 228 (in Chinese)

Xu J T (徐锦堂), Y Z Ran (再砚珠), C Mou (牟春), C F Wang (王成福), J M Cao (曹建民), M Wang (王铭) and J Z Lu (鲁继周), 1981. A brief report on the nutritious sources of seed germination of Gastrodia elata. Bulletin of Chinese Material Medica (中药通报), 6(3): 2 (in Chinese)

Xu J T (徐锦堂) and S X Guo (郭顺星), 1989. Fungus associated with nutrition of seed germination of Gastrodia elataMycena osmundicola Lange. Acta Mycologica Sinica (真菌 学报), 8(3): 221 22 (in Chinese)

Zhang J Y (张建勇), Z J Liu (刘仲健), S P Lei (雷嗣鹏) and L J Chen (陈利君), 2001. Notes on Paphiopedilum wardii and its related species. Acta Phytotaxonomica Sinica (植物分类学报), 39(6)：562 567 (in Chinese)

(责任编辑 : 孙大川) 